\title{
A Report from Washington
}

$\mathrm{M}$

ORE THAN A THOUSAND BILLS in the field of education were introduced in the 85 th Congress. A number of these proposals have significance for the libraries of colleges and universities.

\section{BILLS PASSED}

\section{National Defense Education Act}

One of the last acts of the 85th Congress was the appropriation of $\$ 40$ million to launch the National Defense Education Act of 1958, which was enacted just before adjournment. The cost of the four-year program has been estimated at $\$ 887$ million. Public Law 85-864 is a compromise measure, drafted by a House-Senate conference committee. The legislation sets up a basic four-year program of repayable loans to college students and various aids to spur science, mathematics, and language teaching. The outright scholarship provision was eliminated.

Several titles in this new act apply to institutions of higher education and a number of the provisions can be interpreted as significant to libraries and librarians.

Title II, Loans to Students in Institutions of Higher Education, provides Federal assistance in the establishment of student loan funds for making low interest loans to students to pursue their education at colleges and universities. Up to one-half of any loan is cancelled for service as a full-time teacher in a public elementary or secondary school in a state. The Act authorized an appropriation of $\$ 47.5$ million during the current fiscal year, of which $\$ 6$ million was appropriated initially. Colleges and universities will be required to provide $\$ 1.00$ for every $\$ 9.00$ received in Federal funds. Assuming that the loans would average about $\$ 600$ per student, approximately eleven thousand Federally-supported loans

Miss Krettek is Director of ALA's WVashington office. could be made under the amount appropriated for the first fiscal year.

Since school librarians are certificated as teachers in almost all states, these student loans may be interpreted as available to prospective school librarians.

Title IV, National Defense Fellowships. Approximately 160 colleges and universities are eligible to participate in this program to expand graduate education at the Ph.D. level to increase the number of well-trained college teaching personnel. One thousand fellowships are authorized during the current fiscal year and 1,500 during each of the three succeeding years. Preference will be given to nominees interested in teaching in institutions of higher education. In addition to these fellowships, the Act authorizes grants to their institutions to help finance the new or expanded programs.

When conditions set forth in this act have been met, these fellowships may apply to graduate study for librarians, but probably at the doctoral level only.

Title V, Guidance, Counseling, and Testing, authorizes two related programs: one for secondary schools and one for institutions of higher education. Institutions of higher education may apply directly to the Office of Education for contracts to set up training institutes for guidance and counseling personnel. The Act authorizes an appropriation of $\$ 6,250,000$ for support of the training institutes, of which $\$ 2$ million is now available. There are no specific matching requirements. It is estimated that the full sum authorized would provide sixty institutes and training for 2,350 counselors. Library resources in this field will need to be expanded.

Title VI, Modern Foreign Language Development. Under this title colleges and universities may apply for funds to establish short-term or regular session institutes to provide further training for persons teaching foreign languages or preparing to become language teachers. Regulations are al- 
so being prepared under which colleges and universities may receive Federal assistance in the establishment and operation of special centers to provide instruction for future teachers, government personnel, and others in languages now rarely taught in this country, and instruction in the customs, laws, economic systems, and other aspects of the countries concerned.

Institutions which contract with the Office of Education for the establishment and operation of the institutes and centers will require library materials not only in the foreign languages but in fields needed to provide a full understanding of the countries in which such language is used, such as "history, political science, linguistics, economics, sociology, geography, and anthropology." Increased materials and expansion of existing libraries will be required.

Title VII, Research and Experimentation in More Effective Use of Television, Radio, Motion Pictures, and Related Media for Educational Purposes. This title authorizes grants or contracts to public or nonprofit agencies, organizations, and individuals for projects of research and experimentation on this subject. It also authorizes the Commissioner of Education, directly or through grants or contracts, to study the need for increased use of these media, prepare and publish materials useful in encouraging and making better use of such media for educational purposes, and provide technical assistance to state and local educational agencies and institutions of higher education in the use of such media. A first step in this program will be appointment of an advisory committee. The Act authorizes $\$ 3$ million for this program the first year, of which $\$ 500,000$ has been appropriated initially. Some research is expected to get under way at colleges and universities during the second semester of this current academic year.

The provisions of this title will be of tremendous interest to educational institutions throughout the country and should be of interest to all librarians.

Title IX, Science Information Service. This unit is established in the National Science Foundation. Through it, the Foundation will provide or arrange for indexing, abstracting, translating, and other services leading to a more effective dissemination of scientific information, and will undertake programs to develop new or improved methods for making scientific information available.

\section{Counterpart Funds}

The act to amend and extend the Agricultural Trade Development and Assistance Act of 1954 (P.L.85-931), signed by the President on September 6, 1958, makes it possible to use counterpart funds for abstracting, translating, indexing, acquiring, and otherwise making available in the United States materials from abroad. Specifically, it provides "For financing under the direction of the Librarian of Congress, in consultation with the National Science Foundation and other interested agencies, in such amounts as may be specified from time to time in appropriation acts, (1) programs outside the United States for the analysis and evaluation of foreign books, periodicals, and other materials to determine whether they would provide information of technical or scientific significance in the United States and whether such books, periodicals, and other materials are of cultural or educational significance; (2) the registry, indexing, binding, reproduction, cataloging, abstracting, translating, and dissemination of books, periodicals, and related materials determined to have such significance; and (3) the acquisition of such books, periodicals, and other materials and the deposit thereof in libraries and research centers in the United States specializing in the areas to which they relate."

\section{Educational Exchanges}

In enacting the appropriations bill for the Department of State, the Senate increased the funds for the international educational exchange program. This program received $\$ 20.8$ million last year, the Administration requested the same sum for the coming year, and the House allowed the full amount of the request. The Senate, however, voted $\$ 30.8$ million for international exchange of students, teachers, leaders, and specialists. In conference, agreement was reached on a total of $\$ 22.8$ million. All the increase is 
specifically earmarked for Latin-American exchanges.

In addition to the funds directly appropriated, the international educational exchange program also is authorized to use foreign currencies derived from sale abroad of surplus United States agricultural commodities. Last year, about $\$ 3.5$ million was available from this source. The House voted to permit use of $\$ 6.75$ million in foreign currencies for educational exchanges during the coming year, and the Senate approved use of $\$ 8.75$ million. The compromise figure agreed upon by the conferees was $\$ 7.25$ million.

\section{Research Grants}

Public Law 85-934 authorizes Federal departments and agencies to make or enter into contracts for basic scientific research at nonprofit institutions of higher education, or at nonprofit organizations whose primary purpose is the conduct of scientific research.

\section{Tariff-Free Audio-Visual Materials}

The President signed Public Law 85-458 on June 13, 1958, which permits colleges, schools, and other institutions promoting the arts, sciences, and education to import free of duty sound recordings, slides, and transparencies for its own use or for the encouragement of the fine arts and also permits such institutions to import free of duty picture film to be used in certain nonprofit television broadcasts. The provisions of the Tariff Act of 1930 which exempts from duty books, maps, and similar articles for educational and nonprofit use is thus brought up-to-date with the addition of materials used in educational radio and television broadcasts.

\section{Medical Teaching Facilities Construction}

The Congress passed H.R.12876 which extended for three years the Health Research Facilities Act of 1956 which established a program of Federal matching grants for the construction of health research facilities. This bill has been signed into law (P.L.85777).

The Congress did not act on the bill (H.R.11913) to amend the Public Health
Service Act to authorize grants for research and teaching facilities for existing and new medical, dental, and public health schools. Frederick G. Kilgour, librarian of Yale Medical Library, filed a statement for ALA with the House Subcommittee on Health and Science in support of the proposals which would stimulate the equipping and construction of health libraries as a section of health research and teaching facilities.

\section{Postal Rates}

On May 27, 1958, President Eisenhower signed Public Law 426, 85th Congress, the combined postal rate and postal pay bill (H.R.5836). It will go into effect on various dates until July 1, 1961, though most rates became effective August 1, 1958. New rates are:

\section{First-Class Mail}

\begin{tabular}{|c|c|c|}
\hline $\begin{array}{l}\text { Regular } \\
\text { letters-4 } 4 \text { ounce }\end{array}$ & $\begin{array}{l}\text { Airmail } \\
\text { Airmail }\end{array}$ & $-7 \phi$ ounce \\
\hline $\begin{array}{l}\text { Post- } \\
\quad \text { cards }-3 \phi \text { each }\end{array}$ & cards & $-5^{\phi}$ eac \\
\hline
\end{tabular}

\section{Second-Class Mail}

No change was made in the present second-class rates for publications of nonprofit organizations or for classroom use, except that in no case will the charge per piece be less than the present minimum of $1 / 8$ of a cent.

\section{Third-Class Mail}

Per Piece Rate: $3 \phi$ two ounces, $11 / \mathrm{q}^{\dot{\varphi}}$ each additional ounce.

Bulk: per piece, $2 \phi$, effective January 1 , 1959 , and $21 / 2 \phi$, effective July 1 , 1960. Applicable to qualified nonprofit, religious, educational, scientific, philanthropic, agricultural, labor, veteran, or fraternal organizations and associations-except that the minimum charge per piece will be half the regular minimum charge. Weight limit increased from 8 ounces up to, but not including 16 ounces. The first increase will not affect nonprofit groups since their present rate is $I^{\phi}$ per piece, but the 1960 increase will move their rate up to $11 / 4$ per piece.

\section{Fourth-Class Mail}

Educational Materials (formerly called Book Rate): increased to $9 \phi$ on the first 
pound and $5 \xi$ on each succeeding pound. The following materials, when in parcels not exceeding seventy pounds in weight, may be sent at this rate (underlined are the materials added by the new act): (1) books permanently bound for preservaion consisting wholly of reading matter or scholarly bibliography or reading matter with incidental blank spaces for students' notations and containing no advertising matter other than incidental announcements of books; (2) sixteen-millimeter films and sixteen-millimeter film catalogs, except when sent to commercial theaters; (3) printed music whether in bound form or in sheet form; (4) printed objective test materials and accessories thereto used by, or in behalf of, educational institutions in testing of ability, aptitude, achievements, interests, and other mental and personal qualities with or without answers, test scores, or identifying information recorded thereon in writing or by mark; (5) phonograph recordings; and (6) manuscripts for books, periodical articles, and music.

Library Materials (formerly called $\mathrm{Li}$ brary Book Rate): The present rate of $4 \mathrm{~d}$ for the first pound and $1 \phi$ for each additional pound or fraction is maintained and eligibility includes these categories: (1) books consisting wholly of reading matter or scholarly bibliography or reading matter with incidental blank spaces for students' notations and containing no advertising matter other than the incidental announcements of books; (2) printed music, whether in bound form or in sheet form; (3) bound volumes of academic theses in typewritten or other duplicated form and bound volumes of periodicals; (4) phonograph recordings; and (5) other library materials in printed, duplicated, or photographic form or in the form of unpublished manuscripts.

This rate may also apply to sixteen-millimeter films, filmstrips, transparencies for projection, and slides, microfilms, sound recordings, and catalogs of such materials, when sent in parcels not exceeding seventy pounds in weight to or from (1) schools, colleges, or universities and (2) public libraries, religious, educational, scientific, philanthropic, agricultural, labor, veterans, or fraternal organizations or associations, not organized for profit and none of the net income of which inures to the benefit of any private stockholder or individual.

This rate is extended to include such mail for schools, colleges, and universities in addition to the libraries and nonprofit associations now eligible.

The library materials rate is extended to all delivery zones.

\section{Permit Requirement}

Shipments under the library materials rate may be made without securing a special authorization. The postal manual has been revised so as not to require a permit for the acceptance for such mailings of nonprofit organizations.

There is some ambiguity in the new postal law regarding the minimum weight limit for books. We understand that the Post Office Department will permit such packages weighing less than 16 ounces to be sent at the first pound rate under the book and library book rates ( $9 \phi$ and $4 \phi$ respectively). If any difficulties are encountered on this point with individual post offices, the local postmaster should be requested to secure an official ruling on the question from the Post Office Department in Washington. We understand that such rulings will be as outlined above.

\section{Books for the Blind}

The free mailing privileges for books for the blind are extended to such mail sent without charge by individuals as well as libraries and organizations.

\section{International Book Rates}

On August 25, the Post Office Department announced that the proposed increases in international book post rates which would have raised the book rate to Latin America by 50 per cent and to the rest of the world by $331 / 3$ per cent "are postponed until further notice." ALA, USIA, NEA, and many other groups protested to the Postmaster General that these radical increases would constitute a bar to the free flow of information among nations and to the fostering of a climate of international understanding. A revised proposal is now under consideration by the Post Office Department. 


\section{OTHER Bills INTRODUCED}

\section{Educational Television}

On May 29, the Senate by voice vote passed S.2119, introduced by Senator Warren G. Magnuson (D., Wash.) to authorize Federal grants-in-aid to the states for construction of educational TV facilities. Funds would be available upon application to the U.S. Commissioner of Education and would be granted for facilities operated under the control of a state education agency, a nonprofit organization intending to engage in educational TV broadcasting, a state educational TV commission, or a state college or university. No amount of funds was fixed in the Senate bill, but a limitation of $\$ 1$ million to agencies within any one state was imposed. The bill was approved by the House Interstate and Foreign Commerce Committee but was not approved by the Rules Committee for House floor action.

\section{Depository Library Law}

A final hearing on the bill to revise the depository library law was held in Washington on June 19. Testifying in support of the bill for ALA were Benjamin Powell, librarian, Duke University, and chairman of ALA's Public Documents Committee; Roger McDonough, director, New Jersey State Library; and Jerome Wilcox, librarian, City College, New York City. Arthur H. Parsons, Jr., director, Enoch Pratt Free Library, was unable to be present but submitted a statement which made a part of the printed hearings.

On June 25, Representative Wayne Hays (D., Ohio) introduced a revised bill, H.R. 13140. This bill passed the House of Representatives without amendment on July 21 and was referred to the Senate Rules and Administration Committee. The Committee agreed they favored the general purposes and objectives of the measure but felt hearings should be held. Since no time was available prior to adjournment no further action was taken. It is anticipated a similar bill will be introduced early in the 86th Congress.

The principal new provisions of the bill are as follows:

(1) Each component of the Federal government shall furnish the Superintendent of Documents a list of its publications, except those "required for official use or those required for strictly administrative or operational purposes which have no public interest or educational value and publications classified for reasons of national security," which it issues outside the Government Printing Office.

(2) These publications will be listed by the Superintendent of Documents and distributed by him to such depository libraries as select them.

(3) Additional depository libraries may be designated. The provision "that a total of not more than two such libraries, other than those specifically designated by law ... may be designated within each area" would permit 515 new depositories to be created.

(4) Before a new depository library can be designated within a Congressional district, the head of that library shall furnish his Representative with justification of the necessity for the designation, and this shall be signed by the head of each existing depository library within the district and by the head of the library authority of the state in which the depository is to be established.

(5) As many as two regional depository libraries may be designated in each state, territory, and commonwealth. Such depositories shall agree to receive and retain at least one copy of all government publications, either in printed or microfacsimile form, and within the region served shall make its documents freely available on interlibrary loan and for reference service.

(6) Only regional depository libraries must retain documents permanently. The other depositories may dispose of government publications after five years.

The language of the revised bill also requires the Government Printing Office to pay the cost of mailing publications sent to depository libraries.

\section{College Housing Loans}

An amendment to the Housing Act authorizes increased funds for college housing and authorizes long-term Federal loans at low interest rates for the construction of new, or the rehabilitation of existing, class- 
rooms, laboratories, and academic facilities. ALA presented testimony in support of this new title in the assumption that the term "academic facilities" includes libraries. $S .4035$, a general housing bill, passed the Senate but failed by 6 votes in the House. The legislation was called up on suspension of the rules, which requires a favorable vote of two-thirds of those voting.

\section{Public Community Junior College Construction Bill}

Representative Ullman of Oregon introduced H.R.12232, a bill to establish a fiveyear program of Federal grants-in-aid to the states for the construction, expansion, and remodeling of public community junior colleges. This bill was not reported out by the House Education and Labor Committee.

Each of the measures listed above must be re-introduced and again pass the scrutiny of the appropriate committees, if it is to be enacted by the 86 th Congress which will convene next January 7 .

\section{Progress Report on Science Programs}

A subcommittee of the Senate Committee on Government Operations has issued a Progress Report on Science Programs of the Federal Government, Senate Report No. 2498, 85th Congress, 2nd Session. This report provides a valuable summary of legislative and administrative actions taken on science programs during the current year.

The report is for sale by the Superintendent of Documents, Government Printing Office, for $25^{\phi}$ a copy, but a limited number of free copies is available to libraries and other institutions from the Committee on Government Operations, Room 249, Senate Office Building, Washington 25, D.C.

\section{Conference of Eastern College Librarians}

\section{Scheduled for November 29}

The 44th Annual Conference of Eastern College Librarians will meet at 10:00 a.m. on Saturday, November 29, 1958, in the Harkness Academic Theater, Butler Library, Columbia University, New York.

The morning session is to be devoted to a panel discussion on "The Truth about Cooperation among Libraries." Verner W. Clapp, president, Council on Library Resources, Inc., is the moderator and the panelists are Eileen Thornton, librarian, Oberlin College; Ralph T. Esterquest, librarian, Schools of Medicine and Public Health, Harvard University; Helmer L. Webb, librarian, Union College; and Donald T. Smith, administrative assistant to the director of libraries, Boston University. Miss Thornton and Mr. Esterquest have agreed to take the "negative" side of the topic and Mr. Webb and Mr. Smith will support the "positive" view.

Miss Lucile M. Morsch, deputy chief assistant to the Librarian of Congress, will be chairman of the afternoon session, which will be concerned with "Books in Support of an Academic Program." Donald G. Wing, associate librarian, Yale University and Dan Lacy, managing director, American Book Publishers Council, Inc, will be the speakers.

Correspondence concerning the conference should be addressed to Henry Birnbaum, chairman, Program Committee, Conference of Eastern College Librarians, Brooklyn College Library, Brooklyn 10, New York. No advance registration is necessary. 